\title{
Człowiek i technika na polach bitew wojen światowych (Lwów, 21-23 października 2015 r.)
}

$\mathrm{O}$ d kilku lat Zakład Historii Wojskowej Instytutu Historii UR współpracuje z lwowską Narodową Akademią Wojsk Lądowych Ukrainy. Jedną z form wspólnych przedsięwzięć są organizowane polsko-ukraińskie konferencje naukowe, poświęcone szeroko rozumianym dziejom militarnym. W 2015 r. zorganizowana została konferencja nosząca tytuł „Człowiek i technika na polach bitew wojen światowych". Odbyła się ona w budynkach dydaktycznych lwowskiej akademii w dniach 21-23 października 2015 r. W konferencji wzięło udział blisko 100 przedstawicieli polskich i ukraińskich uniwersytetów, uczelni wojskowych, bibliotek, muzeów oraz innych instytucji naukowych.

Konferencja rozpoczęła się 21 października 2015 r. od części oficjalnej, w której na początku odczytano list skierowany do uczestników konferencji napisany przez komendanta akademii, gen. prof. Pawło Tkaczuka. Następnie głos zabrał przedstawiciel konsulatu RP we Lwowie, który w imieniu konsula Wiesława Mazura przywitał zebranych. Później w imieniu ukraińskiego środowiska naukowego głos zabrał prof. Andrij Kharuk, który przedstawił najważniejsze założenia programowe spotkania. Cześć oficjalną zamknęło wystąpienie dr. hab. prof. UR Andrzeja Olejki, który przedstawił zarys tematyki konferencji i szerokie spectrum poruszanych na obradach zagadnień.

Kolejnym punktem programu stanowiły obrady plenarne, w których głos zabrało siedmiu prelegentów. Jako pierwszy wystąpił dr hab. prof. Wołodymyr Trofymowycz. Jego wystąpienie, zatytułowane ,Od konferencji w Jałcie (Krym) w 1945 r. do aneksji półwyspy w 2014 (lekcje dla Ukrainy)", poświęcone zostało kwestiom politycznym związanym z wpływem ustaleń z okresu II wojny światowej na współczesną sytuację geo- 
polityczną. Następnie głos zabrał prof. dr hab. Henryk Ćwięk, którego wystąpienie noszące tytuł „O rozszyfrowaniu tajemnic Enigmy podczas II wojny światowej”, przybliżało zebranym polski wkład z złamanie niemieckich kodów wojskowych w okresie II wojny światowej. Po nim wystąpił dr hab. doc. Wasyl Hułaj, który skupił się na współczesnych zagadnieniach związanych z zagrożeniami dla bezpieczeństwa w kontekście ,wojny hybrydowej”. Następnie głos oddano dr. hab. prof. Zdzisławowi Cutterowi, którego referat zatytułowany został „Rozbudowa i modernizacja jednostek saperskich WP w okresie zagrożenia wojennego 1935-1939”. Po tym wystąpieniu nastąpiła krótka przerwa, po której obrady kontynuowano.

W drugiej części obrad plenarnych głos zabierał jako pierwszy dr hab. doc. Oleksandr Demjaniuk, którego prelekcja dotyczyła wyzwolenia obwodu wołyńskiego spod okupacji niemieckiej. Następnie głos oddano dr. hab. prof. Piotrowi Semkowowi, który pokazał, w jaki sposób natura wpływała na przebieg konfliktów zbrojnych. Ostatnie wystąpienie w sesji plenarnej tego dnia nosiło tytuł „Współczesne formy międzypaństwowej obrony jako przedmiot badania współczesnej wojskowej myśli", a wygłosił je dr doc. Andrij Slusarenko.

Następnym punktem programu było zwiedzanie kompleksu szkoleniowo-dydaktycznego akademii, w tym m.in. muzeum i sali tradycji. Ostatnim elementem spotkania tego dnia była kolacja, która odbyła się w klubie garnizonowym.

Drugi dzień konferencji, 24 października 2015 r., poświęcony był przede wszystkim na obrady w sekcjach. Sekcja 1 obejmowała wystąpienia dotyczące historii i rozwoju uzbrojenia i techniki wojskowej. Sekcja 2 zaś referaty skoncentrowane na problemach rozwoju sztuki wojennej, ze szczególnym uwzględnieniem XX w., w tym wojen światowych. Ostatnia z sekcji obejmowała tematykę szeroko rozumianego czynnika ludzkiego w aspekcie konfliktów zbrojnych.

Każda z sekcji zawierała tak dużą liczbę wystąpień, że przedstawianie każdego $\mathrm{z}$ nich $\mathrm{w}$ tym miejscu jest trudne. $\mathrm{Z}$ tego względu zaprezentowane zostaną najciekawsze $\mathrm{z}$ nich, dające obraz poruszanych kwestii.

W sekcji 1 na szczególną uwagę zasługuje wystąpienie dr. hab. prof. UAM Macieja Franza, który przybliżył mało znaną kwestię włoskich „,̇ywych torped" i ich bojowego użycia w czasie II wojny światowej. Z kolei dr doc. Mychajło Kołomijeć zajął się problemem współdziałania człowieka z pojazdami pancernymi na polu walki. Doktor Zbigniew Zielonka natomiast przybliżył obecnym zagadnienie rozwoju chemicznych środków walki, szczególnie w okresie I wojny światowej. Doktor Andrij Bakał zaś dokonał analizy ewolucji wieloprowadnicowych wyrzutni rakietowych 
i perspektywy ich dalszego rozwoju. Bardzo interesujące kwestie, związane z rozwojem technologii i taktyki walki myśliwskiej, przedstawił mjr dr Justin Bronder, reprezentant US Air Force. Ogółem w sekcji 1 wygłoszono 27 referatów.

W sekcji 2 poruszano bardzo ciekawe kwestie związane z szeroko rozumianą sztuką wojenną. I tak np. dr Tomasz Grzegorczyk zajął się doświadczeniami operacyjnymi i taktycznymi oraz uzbrojeniem $\mathrm{z}$ okresu wielkiej wojny w polskiej kampanii na Ukrainie wiosną i latem 1920 r. Z kolei dr doc. Witalij Wyzdryk scharakteryzował udział Ukraińców w radziecko-polskiej wojnie 1939 r. Doktor Anna Marcinkiewicz-Kaczmarczyk przybliżyła techniki walki nieregularnej stosowane w kobiecych oddziałach ZWZ-AK. Doktor doc. Stepan Jakymjak dokonał analizy rozwoju strategii wojskowo-morskiej w przeddzień i podczas II wojny światowej. Z kolei dr Jarosław Serednyćkyj wygłosił referat zatytułowany „Trzy Krymskie i Północnokaukaska katastrofy Armii Czerwonej 1941-1942 lat". To jedynie wybrane wystąpienia spośród 33 prelekcji. Sekcja 2 była najliczniej obsadzoną spośród wszystkich paneli na konferencji.

Sekcja 3 rozpoczęła swoje obrady od wystąpienia dr. Andrzeja Drzewieckiego, którego referat nosił tytuł „Człowiek w szponach wojny”, i dotyczył szeroko rozumianego wpływu konfliktu na życie przeciętnego człowieka. Oprócz tego referatu wymienić można wystąpienie dr. Andrija Naumenki, który omówił kwestie służby Ukraińców w armii rosyjskiej w czasie I wojny światowej. Doktor hab. Jerzy Prochwicz przedstawił „Społeczne, polityczne i ekonomiczne skutki I wojny światowej”. Doktor Olga Hapiejewa przybliżyła mało znane zagadnienia związane z działaniem kobiecymi oddziałami lotniczymi w wojnie niemiecko-radzieckiej, z kolei dr Ihor Jewsiejew - sposób funkcjonowania systemu materialnej stymulacji działalności bojowej składu osobowego czynnej armii w czasie Wielkiej Wojny Ojczyźnianej Związku Radzieckiego. W sumie na tej sekcji wysłuchano 25 wystąpień.

Obrady sekcyjne stanowiły główny, merytoryczny punkt programu, ale nie jedyny. W godzinach popołudniowych uczestnicy konferencji udali się na zwiedzanie Lwowa pod kątem jego historii militarnej. Zwieńczeniem tej nieoficjalnej części był kolacja w jednej z lwowskich restauracji.

Ostatni dzień konferencji obejmował dokończenie obrad poszczególnych sekcji. Po nich, ok. godz. 12.00, uczestnicy ponownie zebrali się we wspólnym posiedzeniu, na którym dokonano podsumowania trzydniowych obrad. Na zakończenie reprezentantom poszczególnych instytucji, których przedstawiciele wzięli udział w spotkaniu, wręczono pamiątkowe dyplomy oraz zdjęcia. Konferencja została oficjalnie zamknięta o godz. 13.00. 
W toku obrad poruszano szereg kwestii, które niejednokrotnie były szeroko dyskutowane, nie tylko w ramach części dyskusyjnej na sekcjach, ale także w kuluarach. Bardzo ważnym osiągnięciem konferencji były jednak nie tylko ustalenie stricte naukowe, ale przede wszystkim okazja nawiązania osobistych kontaktów między przedstawicielami polskiego i ukraińskiego środowiska naukowego. Jest to tym istotniejsze, że w toku dyskusji niejednokrotnie zauważano, że oba środowiska często w niewielkim stopniu wymieniają się ustaleniami badawczymi. Aby dalej rozwijać tę współpracę, przedstawiciele komitetu organizacyjnego z Polski i Ukrainy wstępnie ustalili, że także w przyszłości będą organizowane podobne konferencje. $\mathrm{Na}$ chwilę obecną najbardziej prawdopodobne wydaje się zorganizowane przez Instytut Historii UR kolejnej, polsko-ukraińskiej konferencji na jesieni 2016 r., tym razem w Rzeszowie. Informacje na ten temat zostaną rozesłane do przedstawicieli środowiska historycznego w Polsce po skonkretyzowaniu tych wstępnych ustaleń. Liczymy, że podobnie jak to miało miejsce w przypadku omawianej tutaj konferencji, także kolejne spotkanie spotka się z zainteresowaniem badawczym zarówno z Polski, jak i Ukrainy, a być może także innych państw. 